\title{
CAPITAL PUNISHMENT IN THE PERPECTIVE OF NON DEROGABLE RIGHTS
}

\author{
Setiawan Noerdajasakti \\ Fakultas Hukum Universitas Brawijaya Jl. Mayjen Harjono 169 Malang \\ Email : Setiawan.Sakti@ub.ac.id Telepon 08123310381
}

\begin{abstract}
Capital punishment is still exist as one of kind punishments in Indonesia. The existence of capital punishment is based on the Penal Code and other laws. On the other hand, however, according to Constitution 1945, MPR Decree Number XVII/MPR/1988 on Human Rights and Law Number 39 / 1999 on Human Rights, the right to live cannot be limited under any circumstances (non derogable). Capital punishment and the right to live as the right that cannot be limited under any circumstances (non derogable) are contradictive. This contradiction results a conflict of norm between legislations that legalize the existence of capital punishment and legislations that legalize the existence of the right to live. Solutions should be resulted to solve the conflict of norms.
\end{abstract}

Keywords: human rights, non derogable rights, capital punishment, right to live, conflict of norms.

\section{INTRODUCTION :}

In 1998, a political movement happened in Indonesia. Most of Indonesian people, especially university students and politicians forced President Soeharto to resign from his posisition as the president of The Republic of Indonesia. Besides, the people also forced the government to start reformation in many aspects, especially in the aspect of politics and democracy.

During the political movement, political and economic conditions in Indonesia becomes worse and uncotrolable. It is very difficult for the government to control the social condition. Considering that it is not posible to defence his position, finally in May 1998 the president resigned. He resigned after governing Indonesia for more than thirty years.

Since the time of the resignation of Soeharto, the political and economic conditions becomes better and controlable. Democracy also grew well. Indonesia started the new era, that is Reformation Era. Reformation in Indonesia results many kind of changes, including change in the aspect of human 
rights protection. Being compared with the former era that did not give enough attention to the aspect of human rights protection, Reformation Era gives better attention to the human rights aspect. Several kind of legislations that regulate human rights are resulted during the Reformation Era. Substances of these legislations focus on the aspect of human rights protections.

First human rights legislation was produced by MPR RI ${ }^{1}$ (People Representative Assembly of The Republic of Indonesia). That is MPR Decree Number XVII/MPR/1988 on Human Rights. The decree was legislated by MPR at the time when the MPR hold general assembly on November 1998. Substances of the decree that consist of Human Rights Charter and human rights articles give protection on many aspects of human rights. The next human rights legislation raised in the following year. In 1999, DPR RI ${ }^{2}$ (Indonesian Parlement) and Indonesian government legislated Law number 39 / 1999 on Human rights. The law consists of more than 100 articles. Similar to the MPR decree, contents of

\footnotetext{
1 Majelis Permusyawaratan Rakyat Republik Indonesia.

${ }^{2}$ Dewan Perwakilan Rakyat Republik Indonesia.
}

the Law on Human Rights also give protection on many aspects of human rights.

Amending the content of Constitution 1945 is one of the Indonesian people need to continue the reformation. Since the beginning of Reformation Era the amendment of Constitution 1945 has been conducted four times. Firstly, the amendment was conducted in 1999. Then the second amendment was conducted in 2000. In 2001 the amendment of Constitution 1945 was conducted for the third time. Finally the last amendment happened in 2002. The amendments were carried out when MPR RI hold yearly general assembles. ${ }^{3}$

In 2000, when MPR RI conducted the second amendment, special chapter that regulates human rights was included to the constitution. Number of the chapter is Chapter XA and title of the chapter is Human Rights. The chapter consists of 10 articles. Each of the articles are devided into several sub articles. Like the MPR Decree and Law on Human Rights, this chapter also regulates many aspects of human rights. That is why since the second

\footnotetext{
${ }^{3}$ Moch. Mahfud MD, Membangun Politik Hukum Penegakan Konstitusi, (Jakarta : LP3ES, 2006), hlm. 145.
} 
amendment, Constitution 1945 is called as Human Rights Constitution that means constitution that gives constitutional protections to the human rights. $^{4}$

Since the second amendment of Constitution 1945, it can be concluded that there are three kinds legislations that regulate human rights. That are Constitution 1945, MPR Decree Number XVII/MPR/1988 on Human Rights and Law Number 39 / 1999 on Human Rights. According to the hierarchy of legislations, position of these three legislations are on the different levels. ${ }^{5}$ The position of Constitution 1945 is in the first level, the position of MPR Decree Number XVII/MPR/1988 on Human Rights is in the second level and the position of Law Number 39 / 1999 on Human Rights is in the third level. The existence of three kinds of legislations that regulate human rights has the meaning that according to the legal aspect, the human rights have the important role. Moreover, according to the hierarchy,

\footnotetext{
4 Tinton Slamet Kurnia, Konstitusi HAM, Undang-Undang Dasar Negara Pepublik Indonesia Tahun 1945 \& Mahkamah Konstitusi Republik Indonesia, (Jogyakarta : Pustaka Pelajar, 2014), hlm.1.

5 Law Number 12 / 2011 on Legislations Formulation, Article 7 Sub Article (1) .
}

position of these three regulations are in the different levels.

Either Constitution 1945, MPR Decree Number XVII/MPR/1988 on Human Rights or Law Number 39 / 1999 on Human Rights regulate many kind aspect of human rights. Human rights that cannot be limited under any circumstances are also mentioned in those three regulations. Articles that regulate human rights that cannot be limited under any circumstances are Article 28i Sub Article (1) of Constitution 1945, Article 37 of MPR Decree Number XVII/MPR/1988 on Human Rights and Article 4 of Law Number 39 / 1999 on Human Rights. Those three articles mention human rights that cannot be limited under any circumstances with the same formulation. That is "The right to live, freedom from torture, freedom of thought and conscience, freedom of religion, freedom from enslavement, recognition as a person before the law, and the right not to be tried under law with retrospective effect are all human rights that cannot be limited under any circumstances (non derogable)”. Actually, there is a special terminology to express human rights that cannot be limited under any 
circumstances. That is non derogable rights. ${ }^{6}$

Based on the formulation of the article above, it can be concluded that there are seven kinds of rights that cannot be limited under any circumstances (non derogable). Those are:

1. The right to live ;

2. Freedom from torture ;

3. Freedom of thought and conscience ;

4. Freedom of religion ;

5. Freedom from enslavement ;

6. Recognition as a person before the law ;

7. The right not to be tried under law with retrospective effect.

The right to live is one of seven kind of rights that cannot be limited under any circumstances (non derogable). Among kind of the rights that cannot be limited under any circumstances (non derogable), either in Constitution 1945, MPR Decree Number XVII/MPR/1988 on Human Rights or in Law Number 39 / 1999 on Human Rights, position of the right to live is always written in the first position. It means that among other

\footnotetext{
${ }^{6}$ Rizky Ariestandi Irmansyah, Hukum Hak Asasi Manusia dan Demokrasi, (jogyakarta : Graha Ilmu, 2013), hlm. 66.
}

rights that cannot be limited under any circumstances (non derogable), the right to live is the most important one.

On the other hand, capital punishment is still exist in Indonesia. There are several regulations that regulate the existence of capital punishment. KUHP ${ }^{7}$ (Indonesian Penal Code) is the main law that regulates the existence of capital punishment. Besides, several other kinds of laws also legalize the capital punishment.

Article 10 of the Penal Code mentions kind of punishments. This article is the main yuridical base of the capital punishment. The article mentions:

The punishment are :

a. Basic punishment :

1. Capital punishment ;

2. Imprisonment ;

3. Light imprisonment ;

4. Fine.

b. Additional punishment :

1. Deprivation of certain rights ;

2. Forfeiture of specific property ;

3. Publication of juridical verdict. 
According to Article 10 of the Penal Code, capital punishment is one of kind punishments. Among kind of the punishments, position of capital punishment is written in the first position. It means that among other punishments, capital punishment is the hardest one. ${ }^{8}$ Indonesian Penal Code is devided into three books. Book One consists of regulations that regulate General Provisions, such as legal principles, kind of punishments and others. Book Two consists of articles that indicate kind of criminal acts that are classified as crime. Then, book three consists of articles that indicate kind of criminal acts that are classified as misdemeanous. Each of the articles are threatened by penalties. Kind of penalties refere to Article 10 of the Penal Code.

Based on the book two of the Penal Code, kind of acts that are classified as criminal acts are varied. Kind of punishments that are threatened in those criminal acts are also varied. There are several criminal acts that are threatened by capital punishment. Those are murder, president and vice president murder, skyhijacking, et cetera. Not

\footnotetext{
Read Article 69 Sub Article (1) of The Penal Code.
}

only the Penal Code, but capital penalty also threatened by other kind of laws. The laws are such as Law on Narcotics, Law on Psichotropics, Law on Terrorism, Law on Human Rights Court, Law on Corruption, Law on Child Protection and Law on Economic Crime.

Either capital punishment or right to live as the right that cannot be limited under any circumstances (non derogable) have their own juridical bases. Each of the juridical base is still exist. The existence of capital punishment is based on the Penal Code and some other laws. The existence of the right to live as the right that cannot be limited under any circumstances (non derogable), on the other hand, is based on Constitution 1945, MPR Decree Number XVII/MPR/1988 on Human Rights and Law Number 39 / 1999 on Human Rights. Actually, capital punishment and the right to live as the right that cannot be limited under any circumstances (non derogable) are contradictive. This contradiction results a conflict of norm between legislations that legalize the existence of capital punishment and legislations that legalize the existence of the right to live. The conflict of norm results an 
implication to the aspect of legal certainty. Solutions should be resulted to solve the conflict of norms.

\section{METHODOLOGY}

This paper uses juridicalnormative method, including reviewing and analysing the rules of capital punishment in Indonesia. Relevant laws and policy is analysed.

The approach used in this paper is statute approach. Historical development on how Penal Code was formulated will also be considered. It also look at other criminal laws, such as Laws on Narcotics, Law on Corruption, Law on Psichotropic, Law on Terrorism, Human Rights Law, Law on Child Protection and Law on economic Crime. It tries to find whether there was a conflict of norm in formulating capital punishment for specific criminal action.

\section{III.RESULT AND DISCUSSION YUDICIAL REVIEW ON CAPITAL PUNISHMENT}

Several years after MPR RI did the second amendment and legalized the right to live as the right that cannot be limited under any circumstances (non derogable) to the Constitution 1945, there were five narcotic criminals got punishment by the judge. The judge punished them by capital punishment. Two of them are Indonesian citizens, and three others are Australian citizens. The name of two Indonesian citizens are Edith Yunita Sianturi and Rani andriani (Melisa Aprilia). Then, the name of three Australian citizens are Myuran Sukumaran, Andrew Chan and Scott Anthony Rush.

These five narcotic criminals thought that the narcotic law which legalize the existence of capital punishment is contradictive with the legislations which legalize the existence of the right to live as the right that cannot be limited under any circumstances (non derogable). Whereas, based on the hierarchy of legislations, the level position of Narcotic law is lower than the position of Constituton 1945. Based on this opinion, these five narcotic criminals proposed yudicial review on some articles in Narcotic Law to the Constitutional Court. The articles in this case are articles that the judge used as the juridical basic to punish them by capital penalty. Considering that constitutional rights are only served for 
Indonesian citizens ${ }^{9}$, Constitutional Judges in the Constitutional Court refused to examine the yudicial review on some articles in Narcotic Law that was proposed by the three Australian citizens. The Constitutional Judges in Constitutional Court only examined the yudicial review on some articles in Narcotic Law that was proposed by the two Indonesian citizens.

After examining the case, the constitutional judges refused the yudicial review that the two Indonesian citizen proposed. According to the constitutional judges the narcotic law which legalize the existence of capital punishment is not contradictive with the legislations which legalize the existence of the right to live as the right that cannot be limited under any circumstances (non derogable). In the opinion of the constitutional judges, the existence of Indonesian human rights are not absolutely unlimited. The existence of the Indonesian human rights are limited in certain aspects. So, the existence of the right to live as the right that cannot be limited under any circumstances (non derogable) is also limited.

\footnotetext{
${ }^{9}$ Read Article 51 Sub Article (1) Law on Constitutional Court.
}

Constitutional judges consists of nine persons. In spite of the majority of constitutional judges refused the yudicial review that the two Indonesian citizen proposed, however, not all of them agree with the verdict. Two of them have their own opinion that is quite different from the opinion of the seven others. In the opinion of these two constitutional judges the existence of the right to live as the right that cannot be limited under any circumstances (non derogable) is unlimited. The different opinion of these two constitutional judges is explicitelly written in the verdict as the dissenting opinion. Yudicial review that the two narcotic criminals proposed in this case is yudicial review on some articles that legalize the existence of capital punishment in Narcotic Law. It is actually, however, there are some other laws that also legalize the existence of capital punishment, such as Penal Code, Law on Psichotropics, Law on Terrorism, Law on Human Rights Court, Law on Corruption, Law on Child Protection and Law on Economic Crime. The existence of capital punishments that are threatened in some articles of those laws are also contradictive with legislations which 
legalize the existence of the right to live as the right that cannot be limited under any circumstances (non derogable). Based on this condition, it might be possible in future, some other yudicial reviews on those articles in laws will be proposed by some other criminals who got capital punishment by the judge. It might also be possible in future the constitutional judges make another verdict that is quite different from the former verdict.

\section{HUMAN RIGHTS AND THE RESTRICTIONS}

\section{Article 1 Sub Article (3)} Constitution 1945 mentions that "The state of Indonesia shall be a state based on the rule of law". According to Emanuel Kant and Yulius Stahl, rule of law consists of several components. One of the components of rule of law is guaranteeing the existence of legal protection. ${ }^{10}$ The existence of regulation of human rights protection in Chapter XA of Constitution 1945 shows the consistency of Article 1 Sub Article (3) Constitution 1945.

10 Moh. Hatta, Beberapa Masalah Penegakan Hukum Pidana Umum Dan Pidana Khusus, (Jogyakarta : Liberty, 2009), hlm. 8.
Definition of human rights is not mentioned in any articles of Chapter XA of Constitution 1945. Definition of human rights are mentioned in MPR Decree Number XVII/MPR/1988 on Human Rights and Law Number 39 / 1999 on Human Rights. According to the MPR Decree :

"Human right is such a fundamental right that stuck on any human being. It is superior and universal. It is a gift from God. It has function to guarantee the continuity of life, freedom and development of human being and society. It is unable to be ignored, seized and disturbed by anyone”.

According to Article 1 Law Number 39 / 1999 on Human rights :

"Human rights are a body of rights that is stuck to the essence and the existence of human being as the creature of Supreme God. The state, law, government and anyone have to give respect, honour and protection to the human rights”.

In spite of definition of human rights is not mentioned in Constitution 1945, Article 28 j Constitution 1945 regulates restrictions that anyone is unable to ignore in expressing the human rights. Formulation of the article is as follows : 
(1) Every person shall have the duty to respect the human rights of others in the orderly life of the community, nations and states.

(2) In excercising his/her rights and freedoms, every person shall have the duty to accept the restrictions established by law for the sole purposes of guaranteeing the recognition and respect of the rights and freedoms of others and of satisfying just demands based upon considerations of morality, religious values, security and public order in democratic society.

Not only Article 28 j Constitution 1945, but Article 36 MPR

Decree Number XVII/MPR/1988 on Human Rights and Article 70 Law Number 39 / 1999 on Human Rights also regulates restrictions that every person is unable to ignore in excercising his/her rights. Formulation of the both articles are the same as the formulation of Article 28 j Sub Article (2) Constitution 1945.

These three articles, either Article 28 j Constitution 1945, Article 36 MPR Decree Number
XVII/MPR/1988 on Human Rights or Article 70 Law Number 39 / 1999 on Human Rights show an indication that the existence of Indonesian human rights are restricted. The restrictions are such as human rights of others, restrictions established by law, morality, religious values, security and public order . Based on these restrictions, it migh be possible that the constitutional judges have the opinion that Indonesian human rights, including the right to live, are not absolutely limited. Then they wrote their opinion as the base of their verdict.

\section{NON DEROGGABLE RIGHTS AND THE RESTRICTIONS}

The words "derogable rights" and the words "non derogable rights" are well-known in literature of human rights. The word “derogable rights” or "derogable human rights" means the rights that can be decreased by the government in certain condition. Or in other words "derogable rights" means the rights with restrictions. On the other hand, the word "non derogable rights" or "non derogable human rights" means the rights that cannot be decreased by the government, in spite of it is in the emergency situation. Non derogable is a 
specific characteristic of certain human rights that is unable to be restricted. ${ }^{11}$ In other words Non derogable is a specific characteristic of certain human rights that cannot be limited under any circumstances.

Either Article 28i Sub Article (1) of Constitution 1945, Article 37 of MPR Decree Number XVII/MPR/1988 on Human Rights and Article 4 of Law Number 39 / 1999 on Human Rights mention seven kinds of rights that cannot be limited under any circumstances (non derogable). Those are the right to live, freedom from torture, freedom of thought and conscience, freedom of religion, freedom from enslavement, recognition as a person before the law and the right not to be tried under law with retrospective effect. Constitution 1945 and MPR Decree Number XVII/MPR/1988 on Human Rights do not give detail explaination about the meaning of the words "rights that cannot be limited under any circumstances”. Further explanation about those words is mentioned in the explanation of Article 4 Law Number 39 / 1999 on Human Rights such as folows :
"Meaning of "under any circumstances" includes war situation, arm conflict, or state emergency. The rights cannot be limited by "anyone”. The word anyone in this case includes state, government or social members”.

According to the explanation of Article 4 Law Number 39 / 1999 on Human Rights, non derogable rights cannot be limited under any circumstances, eventhough it is under war situation, arm conflict, or state emergency. Based on this explanation, during normal situation non derogable rights of course cannot be limited under any circumstances, including right to live as one kind of non derogable rights.

Considering that the specific characteristic of non derogable rights that is unable to be restricted, argumentation of constitutional judges that the existence of Indonesian human rights are not absolutely unlimited cannot be implemented to non derogable rights. It also means that the right to live is also unable to be restricted. Based on this agumentation, it can be concluded that the existence of capital penalty is contradictive with the Constitution 1945.

\footnotetext{
${ }^{11}$ Rizky Ariestandi Irmansyah, loc.cit.
} 
CONTRADICTION BETWEEN RIGHT TO LIVE AND CAPITAL PENALTY FROM THE LEGAL CERTAINTY POINT OF VIEW

Goal of law consists of three aspects, such as legal certainty, legal equity and legal utility. ${ }^{12}$ The existence of legislations results legal certainty. The existence of legislations that legalize the right to live as the right that cannot be limited under any circumstances (non derogable) show legal certainty. The existence of legislations that legalize the existence of capital punishment also shows legal certainty. Legal certainty among those contradictive legislations results conflict of norm.

In future, the Indonesian Penal Code that is inherited by the Dutch, will be changed with the new one. Unfortunately, capital penalty is still explicitely mentioned in some articles of the draft of the Penal Code. It means that in future conflict of norm between right to live and capital punishment will happen. The government and the parlement should do something to solve this problem.

Marwan Mas, Pengantar Ilmu Hukum, (Jakarta : Ghalia Indonesia, 2004), hlm. 74 .
What the government and the parlement should do is related to the criminal law policy or penal policy. It means efforts to form criminal law legislations especially legislation that related to capital penalty should be prepared and considered as carefull as possible. It should look at the situation and condition. ${ }^{13}$ Especially condition of any regulations that are relalted to capital penalty and right to live as one of the right that cannot be limited under any circumstance (non derogable).

\section{LOOKING AT THE RIGHT TO} LIVE AND CAPITAL PENALTY FROM INTERNATIONAL INSTRUMENTS

Article 3 Universal Declaration of Human Rights mentions that "everyone has the right to live, liberty and security of person”. This regulation has the meaning that te right to live is guaranteed by the Universal Declaration of Human Rights. Not only Universal Declaration of Human Rights, another International instrument, that is International Covenant on Civil and Political Rights also gives juridical base on the right to live. Article 6 Sub

13 Barda Nawawi Arief, Kebijakan Hukum Pidana (Penal Policy), (Semarang : FH UNDIP, 1995), hlm. 6. 
Article (1) of International Covenant on Civil and Political Rights mention that "Every human being has the inherent right to live. This right shall be protected by law. No one shall be arbitrarily deprived of his life”. Based on Article 6 Sub Article (1) of International Covenant on Civil and Political Rights, it is clear that right to live shall not be able to be arbitrarily deprived. This article can also be interpreted that right to live is unable to be limited under any circumstances.

\section{CONCLUSION}

Based on Constitution 1945 right to live is the right that cannot be limited under any circumstances (non derogable). Capital punishment is contradictive with Constitution 1945. Implication of this contradiction is all regulations that regulate the existence of capital punishment have to be canceled. The judge is not allowed to punish a criminal with capital penalty. Considering that the right to live is one of the right that cannot be limited under any circumstances (non derogable), in future, when examine another judicial review on another law that legalizes the existence of capital penalty, Constitution Judges should decide that right to live is contradictive with Constitution 1945.

\section{REFERENCES}

\section{BOOKS}

A. Bazar Harahap dan Nawangsih Sutardi, Hak Asasi Manusia dan Hukumnya, Jakarta : Pecirindo, 2007.

Abdul Mukthie Fadjar (I), Hukum Konstitusi dan Mahkamah Konstitusi, Jogyakarta : Konstitusi Press dan Citra Media, 2006.

Abdul Mukthie Fadjar (II), Tipe Negara Hukum, Malang : Bayu Media, 2004.

Abdul Rachmad Budiono, Pengantar Ilmu Hukum, Malang : Bayumedia, 2005.

Ahmad Sukardja, Piagam Madinah \& Undang-Undang Dasar NRI 1945, Kajian Perbandingan Tentang Dasar Hidup Bersama Dalam Masyarakat Yang Majemuk, Jakarta : Sinar Grafika, 2012.

Andi Hamzah (I), Asas -Asas Hukum Pidana, Jakarta : Rineka Cipta, 1994.

Andi Hamzah dan A. Sumangelipu (II), Pidana Mati di Indonesia, Di Masa Lalu, Kini dan Masa Depan, Jakarta : Ghalia Indonesia, 1984.

Andi Hamzah (III), Delik-Delik Tersebar di Luar KUHP dengan Komentar, Jakarta : Pradnya Paramita, 1985. 
E. Utrecht, Rangkaian Sari Kuliah Hukum Pidana I, Surabaya : Pustaka Tinta Mas,1987.

H. Muchsin, Ikhtisar Ilmu Hukum, Jakarta : Badan Penerbit Iblam, 2006.

Ishaq, Dasar-Dasar Ilmu Hukum, (Jakarta, Sinar Grafika, 2009.

J.E. Sahetapy, Ancaman Pidana Mati terhadap Pembunuhan Berencana, Malang : Setara Press, 2009.

Jimly Asshiddiqie, Konstitusi Bernegara, Praksis Kenegaraan Bermartabat Dan Berdemokrasi, Malang : Setara Press, 2015.

John M. Echols dan Hassan Shadily (I), Kamus Indonesia Inggris, An Indonesian-English Dictionary, Jakarta : PT. Gramedia Pustaka Utama, 2006.

John M. Echols dan Hassan Shadily (II), Kamus Inggris Indonesia, An English Indonesian Dictionary, Jakarta : PT. Gramedia Pustaka Utama, 2007.

Joko Prakoso, Studi Tentang PendapatPendapat Mengenai Efektifitas Pidana Mati di Indonesia Dewasa Ini, Jakarta : Ghalia Indonesia, 1985.

L.J. Van Apeldoorn, Pengantar Ilmu Hukum, Jakarta : Pradnya Paramita, 1985, hlm. 25.

Marwan Effendi, Teori Hukum Dari Perspektif Kebijakan, Perbandingan
Harmonisasi Hukum Pidana, Jakarta : Referensi Gaung Persada Press Group, 2014.

Mahkamah Konstitusi Republik Indonesia, Naskah Komprehensif Perubahan Undang-Undang Dasar Negara Republik Indonesia Tahun 1945, Latar Belakang, Proses dan Hasil Pembahasan 19992002, Jakarta : Sekretariat Jenderal Dan Kepaniteraan Mahkamah Konstitusi, 2010.

Majda El Muhtaj, Hak Asasi Manusia Dalam Konstitusi Indonesia, Jakarta : Kencana Perdana Media Group, 2015.

Marwan Mas, Pengantar Ilmu Hukum, Jakarta : Ghalia Indonesia, 2004.

Masruchin Ruba'i (I), Asas- Asas Hukum Pidana, Malang : UM Press, 2001.

Masruchin Ruba' (II), Mengenal Pidana dan Pemidanaan di Indonesia, Malang : IKIP, 1997.

Moehadi Zaenal, Pidana Mati dihapus atau dipertahankan, Yogyakarta : Hanindito, 1984.

Moeljatno (I), Asas-Asas Hukum Pidana, Jakarta : Bina Aksara, 1983.

Moeljatno (II), Perbuatan Pidana dan Pertanggungjawaban Dalam Hukum Pidana Pidana, Jakarta : Bina Aksara, 1983.

Moh. Hatta, Beberapa Masalah Penegakan Hukum Pidana 
Umum Dan Pidana Khusus, Jogyakarta : Liberty, 2009.

Moh. Mahfud MD (I), Membangun Politik Hukum Penegakan Konstitusi, Jakarta : LP3ES, 2006.

Moh. Mahfud MD (II), Pergulatan Politik dan Hukum di Indonesia, Jogyakarta : Gama Media, 1999.

Mokhamad Najih, Politik Hukum Pidana, Konsepsi Pembaharuan Hukum Pidana Dalam Cita Negara Hukum, Malang : Setara Press, 2014.

Muladi dan Barda Nawawi Arief (I), Pidana dan Pemidanaan, Semarang : Badan Penyedia Bahan Kuliah FH UNDIP, 1984.

Muladi (II), Hak Asasi Manusia, Hakekat, Konsep Dan Implikasinya Dalam Perspektif Hukum Dan Masyarakat, Bandung : Refika Aditama, 2007.

Nelvitia Purba dan Sri Sulistyawati, Pelaksanaan Hukuman Mati Perspektif Hak Asasi Manusia dan Hukum Pidana di Indonesia, Yogyakarta : Graha Ilmu, 2015.

Nurul Qamar, Hak Asasi Mnusia dalam Negara Hukum Demokrasi, Jakarta : Sinar Grafika, 2013.

PAF. Lamintang dan Franciscus Theojunior Lamintang (I), Dasar-Dasar Hukum Pidana di Indonesia, Jakarta : Sinar Grafika, 2014.
Peter Mahmud Marzuki (I), Pengantar Ilmu Hukum, Jakarta : Kencana Prenanda Media Group, 2013.

Peter Mahmud Marzuki (II), Penelitian Hukum(Edisi Revisi), Jakarta : Kencana, 2015.

R. Soesilo, Kitab Undang-Undang Hukum Pidana (KUHP) Serta Komentar-Komentar Lengkap Pasal demi Pasal, Bogor : Politea, 1983.

Riduan Syahrani, Rangkuman Intisari Ilmu Hukum, Bandung : Citra Aditya Bakti, 2004.

Roeslan Saleh (I), Perbuatan Pidana dan Pertanggungjawaban Pidana - Dua Pengertian Dasar Dalam Hukum Pidana, Jakarta : Aksara Baru, 1983.

Roeslan Saleh (II), Stelsel Pidana Indonesia, Jakarta : Aksara Baru, 1983.

Rizky Ariestandi Irmansyah, Hukum Hak Asasi Manusia dan Demokrasi, Jogyakarta : Graha Ilmu, 2013.

Rozali Abdullah dan Syamsir, Perkembangan HAM Dan Keberadaan Peradilan HAM Di Indonesia, Jakarta : Ghalia Indonesia, 2001.

Schaffmeister, et.al., Hukum Pidana, Yogyakarta : Liberty, 1995.

Sekretariat Jenderal Dewan Perwakilan Rakyat Republik Indonesia, Proses Pembahasan Rancangan Undang-Undang Tentang Hak Asasi Manusia, Jakarta : Sekjen DPR RI, 2001. 
Sudarto (I), Hukum Pidana I, Semarang : Yayasan Sudarto FH UNDIP, 1990.

Sudarto (II), Kapita Selekta Hukum Pidana, Bandung : Alumni, 1981.

Sudikno Mertokusumo, Mengenal Hukum Suatu Pengantar, Jogyakarta : Liberty, 1999.

Sugandi, KUHP dan Penjelasannya, Surabaya : Usaha Nasional, 1981.

St. Harun Pudjiarto RS, Hak Asasi Manusia Kajian Filosofis Dan Implementasinya Dalam Hukum Pidana Di Indonesia, Jogyakarta: Universitas Atma Jaya, 1999.

Teguh Prasetyo, Hukum Pidana Materiil (Jilid I), Jogyakarta : Kurnia Kalam, 2005.

Tinton Slamet Kurnia (I), Konstitusi HAM, Undang-Undang Dasar Negara Republik Indonesia Tahun 1945 \& Mahkamah Konstitusi Republik Indonesia, Jogyakarta : Pustaka Pelajar, 2014.

Tinton Slamet Kurnia (II), Interpretasi Hak-Hak Asasi Manusia Oleh Mahkamah Konstitusi republik Indonesia, The Jimly Court 2003-2008, Bandung : Mandar Maju, 2015.

Tolib Setiady, Pokok-Pokok Hukum Penitensier di Indonesia, Bandung : Alfabeta, 2010.

Tongat, Dasar-Dasar Hukum Pidana Indonesia Dalam Perspektif
Pembaharuan, Malang : UMM Press, Malang, 2009.

Wirjono Prodjodikoro, Asas-Asas Hukum Pidana di Indonesia, Jakarta : Eresco, 1981.

Yan pramadya Puspa, Kamus hukum, Semarang : Aneka Ilmu, 1977.

\section{LEGISLATION}

Undang-Undang Dasar Negara Republik Indonesia Tahun 1945, Lembaran Negara Republik Indonesia Tahun II No. 7 Tahun 1946.

Ketetapan Nomor XVII / MPR / 1998 tentang Hak Asasi Manusia.

Undang-Undang Nomor 1 tahun 1946 tentang Peraturan Hukum Pidana, Staatsblad 1915, Nomor 732 (disebut Kitab UndangUndang Hukum Pidana / KUHP).

Undang-Undang (Darurat) Nomor 12 Tahun 1951 tentang Senjata Api dan Bahan Peledak, Lembaran Negara tahun 1951 Nomor 78, Tambahan Lembaran Negara Nomor 81.

Undang-Undang Nomor 7 (drt) tahun 1955 tentang Tindak Pidana Ekonomi, Lembaran Negara tahun 1955 Nomer 27, Tambahan Lembaran Negara Nomor 801.

Pemerintah Pengganti Undang-Undang Nomor 21 tahun 1959 tentang Memperberat Ancaman Hukuman Terhadap Tindak Pidana Ekonomi, Lembaran Negara Tahun 1959 Nomor 130. 
Undang-Undang Nomor 11 / PNPS / tahun 1963 tentang Pemberantasan Kegiatan Subversi, Lembaran Negara Tahun 1963 Nomor 101, Tambahan Lembaran Negara Nomor 2595.

Undang-Undang Nomor 2/Pnps./1964 tentang Tata Cara Pelaksanaan Pidana Mati yang Dijatuhkan oleh Pengadilan di Lingkungan Peradilan Umum dan Militer, Lembaran Negara Republik Indonesia Tahun 1964 Nomor 38.

Undang-Undang Nomor 4 tahun 1976 tentang Perubahan dan Penambahan Beberapa Pasal Dalam Kitab Undang-Undang Hukum Pidana Bertalian Dengan Perluasan Berlakunya Ketentuan Perundang-

Undangan Pidana, Kejahatan Penerbangan Dan Kejahatan terhadap Sarana / Prasarana Penerbangan, Lembaran Negara Republik Indonesia Tahun 1976 Nomor 26, Tambahan Lembaran Negara Nomor 3080.
Undang-Undang Nomor 5 tahun 1997 tentang Psikotropika, Lembaran Negara Republik Indonesia Tahun 1997 Nomor 10, Tambahan Lembaran Negara Republik Indonesia Nomor 3671.

Undang-Undang Nomor 10 tahun 1997 tentang Ketenaganukliran, Lembaran Negara Republik Indonesia Tahun 1997 Nomor 23, Tambahan Lembaran Negara Republik Indonesia Nomor 3676.

Undang-Undang Nomor 22 tahun 1997 tentang Narkotika, Lembaran Negara Tahun 1997 Nomor 67, Tambahan Lembaran Negara Nomor 3698.

Undang-Undang Nomor 31 tahun 1999 tentang Pemberantasan Tindak Pidana Korupsi, Lembaran Negara Republik Indonesia tahun 1999 Nomor 140, Tambahan Lembaran Negara Republik Indonesia Tahun Nomor 3874. 